\title{
Causes of Bank Suspensions in the Panic of 1893
}

\author{
Mark Carlson \\ Federal Reserve Board
}

There are two competing theories explaining bank panics. One argues that panics are driven by real shocks, asymmetric information, and concerns about insolvency. The other theory argues that bank runs are self-fulfilling, driven by illiquidity and the beliefs of depositors. This paper tests predictions of these two theories using information uniquely available for the Panic of 1893 . The results suggest that real economic shocks were important determinants of the location of panics at the national level, however at the local level, both insolvency and illiquidity were important as triggers of bank panics.

\footnotetext{
"Federal Reserve Board, Mail Stop 86, 20" and Constitution Ave. NW, Washington DC, 20551. Mark.A.Carlson@frb.gov. I have benefited greatly from conversations with Greg Duffee, Barry Eichengreen, and Christina Romer, as well as comments from Richard Grossman and seminar participants at the University of Virginia. Thank you also to Shaun Boyd for generous assistance collecting information about the experience of Colorado during the crisis. The views presented in this paper are solely those of the author and do not necessarily represent those of the Federal Reserve Board or its staff.
} 
The National Banking Era, extending from 1865 until 1913, witnessed five major financial panics (Sprague 1910). These crises caused hundreds of national banks to suspend operations, constituting major disruptions of the financial system. In the Panic of 1893, roughly 575 banks either failed or temporarily suspended operations (Bradstreet's 1893). Clearinghouses in 73 cities partially suspended cash payments in the Panic of 1907. During the three most severe crises, those of 1873, 1893, and 1907, specie was hoarded and circulated at a premium over checks drawn on banks, even in major financial centers such as Boston and New York City. Due to the disruptions in the financial system, some non-financial businesses found it difficult to obtain the funds they needed to meet payrolls and were forced to suspend operations (Noyes 1909). Efforts to eliminate these crises led to the development of many modern financial institutions including the creation of the Federal Reserve System (Calomiris and Gorton 1991).

Two lines of thought have emerged to explain the panics. One argues that panics and suspensions occurred because depositors were concerned about each others' actions (Diamond and Dybvig 1983). According to this theory, the fact that only some of each bank's assets are liquid is critical. Depositors are concerned about the demand for these liquid assets. If deposit withdrawal demand exceeds the volume of liquid assets, the bank may have to liquidate other assets at firesale prices or suspend. The bank operates under a sequential service constraint, so that only the first people in line receive their deposits. Thus, if depositors believe deposit withdrawal demand will exceed the bank's supply of liquid assets, they rush to the bank and precipitate a run. Depositors beliefs about deposit withdrawal demand can be based on a signal or be random, hence this theory has been referred to as the random withdrawal theory.

The second line of reasoning argues that panics are motivated by real economic events (Calomiris and Khan 1991, Gorton 1985). Real shocks cause banks to become insolvent. Depositors know that some banks are insolvent, however they do not know which ones. Banks know when they become insolvent and, if not liquidated, abscond with whatever funds they possess. To prevent insolvent banks from absconding, depositors close all the banks when they witness a shock. If depositors were to have the same information as the banks about each bank's viability, then only the insolvent banks would be closed. Panics are therefore caused by an asymmetry in the information between banks and depositors. Thus, this theory is referred to as the asymmetric information theory. 
These two theories have similar descriptions about the crisis environment. Neither theory requires that banks actually fail during a panic. In both cases, if banks were to meet the withdrawal demands of depositors they would have to liquidate their assets at firesale prices, causing solvent banks to risk becoming insolvent. In both theories, banks can avoid this fate simply by temporarily ceasing operations until either the depositors' demand for their deposits has passed, or until it can be determined which banks are solvent and which ones are not. Both theories indicate that panics should occur in periods of low liquidity. The random withdrawal theory suggests that depositors are ordinarily concerned with their ability to withdraw deposits, so when financial markets are illiquid, depositors should be even more concerned. Under the asymmetric information theory, if depositors test the bank, illiquid markets reduce the bank's ability to meet deposit withdrawals and cause the bank to be more likely to suspend.

While the theories have some similarities, they also have very different predictions about why the panics of the National Banking Era were nationwide. The asymmetric information theory predicts that underlying the nationwide panics were nationwide real shocks. The panics could "spread" only in so far as failures in one region of the country provided information about the solvency of banks in other parts of the country. By contrast, the random withdrawal theory suggests that the financial system could have transmitted the panics from one area to another. A liquidity panic in one region could have pulled reserves away from other regions, causing concerns amongst depositors in the other regions that they would be unable to readily access their deposits, causing additional regional panics. Thus, in order to understand why financial instability in the National Banking Era involved nationwide crises, it is important to determine which of these theories more accurately describes the panics.

A similar debate on the nature of panics is occurring in the international economics literature today. Scholars are arguing over the reasons that the recent financial crisis in East Asia spread from Thailand to other countries. Some scholars (Glick and Rose 1998) argue that the devaluation in Thailand was a negative real economic shock to Indonesia, Korea, Malaysia and other countries because it reduced the competitiveness of their exports. According to the asymmetric information theory, this may have led investors to question the solvency of the East Asian countries and withdraw their funds. Other scholars (Radalet and Sachs 1998) argue that the economies of the East Asian countries were sound and that the Thai crisis caused investors to be 
concerned that other investors would withdraw their money from the region, leading to a random withdrawal type panic. Studying the panics of the National Banking Era may therefore shed light on these modern events as well.

Some effort has already been made to distinguish between the random withdrawal and the asymmetric information theories. In an influential paper, Calomiris and Gorton (1991) examine the span of the National Banking Era and compare the predictions of the two theories regarding the causes, location of failures, and resolution of the panics. They find that the asymmetric information theory is more consistent with events during this period than the random withdrawal theory.

This paper tests the asymmetric information and the random withdrawal theories focusing on the Panic of 1893 because of the unique set of information available about it. After the Panic of 1893, the Comptroller of the Currency published a list of the national banks that suspended but resumed operations as well as the banks that failed. Bradstreet's did the same for all banks national, state, savings, and private. Banks that suspended but resumed operations are presumed to be solvent and were closed solely due to the panic. Examining the reasons that these banks suspended provides a clear test of the two theories. The tests consist of analyzing whether suspending banks were strongly linked to the rest of the banking system through their reserves, a liquidity channel associated with the random withdrawal theory, or whether suspending banks were more likely to be exposed to real shocks than non-suspending banks as suggested by the asymmetric information theory. These tests are conducted using state level aggregates, individual national banks from four states, and all banks in Colorado. Analyzing the data at these three levels allows different aspects of the theories to be tested through a variety of techniques. Additionally comparisons are made across time within the panic of 1893. Sprague (1910) suggests that the panic occurred in two phases, an initial phase in which events from the interior caused the panic, and a second phase in which a suspension in New York spread to the interior. A suspension in New York is a key part of the way the panic spreads in the random withdrawal hypothesis. Thus, according to this theory, there should be significant differences in the effects of financial linkages between the two parts of the crisis.

\footnotetext{
${ }^{1}$ Wicker (2000) suggests that this is largely an accurate assumption.
} 
The results are more consistent with the asymmetric information theory when using state aggregates, but local level evidence displays characteristics of both theories. Comparing the experience of different states reveals a strong positive relationship between indicators of real shocks and bank suspensions and no connection between bank suspensions and the reserve system. In the analysis of both state aggregates and individual national banks the suspension in New York is found to have no effect, contrary to the prediction of the random withdrawal hypothesis. Nonetheless, careful study of events in Colorado reveals behavior that draws from both the random withdrawal and asymmetric information theories.

The paper is organized as follows. Section 2 presents historical background, covering the National Banking Era and the Panic of 1893. Section 3 describes previous theoretical work on the random withdrawal and asymmetric information theories and the empirical work that has tested them. Section 4 tests the two theories using data from the Panic of 1893. Section 5 presents concluding arguments.

\section{Section 2 Historical Background}

\section{Section 2.1 The National Banking Era}

The banking system of the National Banking Era had a pyramidal reserve structure. At the bottom of the pyramid were the numerous national "country" banks. " These were national banks located anywhere in the country outside certain designated cities. "Country" banks were required by law to hold reserves equal to $15 \%$ of outstanding bank notes. Up to $60 \%$ of these reserves could be held as deposits in reserve city banks. All remaining reserves were required to be held as cash. ${ }^{\text {B }}$ The next level of the pyramid consisted of the reserve city banks. Reserve cities were specified by an act of Congress and consisted of large cities such as Boston, Philadelphia, and Kansas City. Reserve city banks were required to have reserves equal to $25 \%$ of outstanding bank notes. Half of these reserves could be held as deposits at banks in central reserve cities and half were required to be held as cash. Thus reserve city banks held deposits

\footnotetext{
${ }^{2}$ A national bank indicates that it was chartered by the national government. There were also many state chartered and private banks that had varying levels of association with the national system.

${ }^{3}$ The requirements for state banks were quite different. Prior to 1887 state banks had few reserve requirements. By the early 1890s state banks were required to hold reserves valued at between $15 \%$ and $25 \%$ of deposits, depending on the state. (States also varied concerning whether reserves needed to be held against all deposits or just checking deposits) One half to three quarters of reserves could be held as deposits in other banks, the rest had to be cash.
} 
from country banks and could place deposits with central reserve city banks. In practice reserve city banks acted as pass-through banks, most of the interbank deposits they received from country banks were placed as deposits at central reserve city banks.

New York City, and later Chicago and St. Louis, were designated as central reserve cities. Throughout the National Banking Era, New York was the primary central reserve city, holding a vast majority of the central reserve cities' interbank deposits. In fact, interbank deposits formed the bulk of the liabilities for several large New York Banks. Sprague (1910) calculates that New York reserve agents had roughly three times the liabilities to bankers as to individuals.

New York banks used a substantial amount of the bank deposits they received to provide loans to brokerage houses involved in the stock and commercial paper/bond markets. Bordo, Rappoport, and Schwarz (1991) calculates that close to $75 \%$ of central reserve city banks' loans were loans to financial firms. The loans could be called in at the banks' discretion and were therefore referred to as "call loans." These loans were thought to be very liquid and thus appropriate for reserve agents to hold.

\section{Section 2.2 The Crisis of 1893}

One of the most severe panics of the National Banking Era occurred during 1893 (Sprague 1910, Kemmerer 1910). Scholars have noted that financial markets were strained even before the crisis. In the months prior to the crisis, the gold reserves of the Treasury were nearing the legal limit required to maintain gold parity. Some contemporary scholars claim that this led to a fear of depreciation and that the crisis was really a run on the currency (Lauck 1907, Noyes 1909). Other contemporary and most modern scholars maintain that concern over gold parity had little effect (Sprague 1910, Friedman and Schwartz 1963, and Wicker 2000) noting both that the treasury reached the limit in late April but the bank runs did not start until June and that the crisis was centered in parts of the country where "there is no evidence that people were distrustful of silver money (Sprague 1910, p. 169)., 5

\footnotetext{
${ }^{4}$ From deposit and loan percentages it appears that money lent by the banks to be invested in the stock market did not return to the banking system in New York in large quantities.

${ }^{5}$ There are other reasons to believe this was not a run on the currency. Of the deposits withdrawn from banks being run, some were hoarded but many were redeposited in other banks. Also, Dun's Review reports that both gold and notes traded at a premium with respect to bank deposits. On some days the premium paid for notes, which would have lost value relative to gold if a depreciation occurred, exceeded that for gold. Regardless, the argument made by
} 
On February $26^{\text {th }}$, the Philadelphia and Reading Railroad, a large Eastern concern, failed. This created some concern about the solvency of other firms and caused a decline in the stock market for the months of March and April (Sprague 1910). On May $5^{\text {th }}$, the National Cordage Company failed. This led to a collapse in the stock market and led to a large increase in the interest rate on call loans (Noyes 1909).

Despite the collapse of stock market prices, money from the interior continued to flow into New York, possibly to take advantage of the high interest rates on call loans. Then in early June, these inflows to New York reversed and money flowed back to the interior. The reverse of flows was large and sudden enough to cause the New York, Boston, Philadelphia, and Pittsburgh Clearinghouses to authorize the issuance of clearinghouse certificates (Noyes 1909). ${ }^{\text {G }}$ There was, however no widespread suspension of payments in these financial centers. Sprague (1910) argues that the reason for the sudden shift was the failure of banks in the South and West.

By the middle of July, the situation seemed to have calmed. Then, on July $25^{\text {th }}$, the Erie Railroad failed. Within two days "suddenly and unexpectedly the banks throughout the country, beginning with those in New York, partially suspended cash payments (Sprague 1910, p.177)." Once New York and some of the other financial centers refused to allow depositors to make large withdrawals, a premium for currency was generated. Noyes (1909) reports widespread hoarding of currency. Banks continued to fail and there was a marked increase in the number of banks completely suspending operations. It was not until September that the currency premium disappeared, banks reopened and the crisis was resolved.

The crisis throughout was regional in nature. It is true that the stock market in New York was unstable and that some of the major Eastern financial centers experienced periods of stress. The areas of the country that were hardest hit, however, were the Mountain, Prairie, and interior Southern states.

The historical narrative describes two real shocks affecting the economy at the time of the crisis. The first is a collapse of the railway industry. Faulkner (1959) describes the railway industry as overextended having lain miles of track that were "not needed, through miles and miles of

\footnotetext{
Lauck and Noyes can be incorporated into the random withdrawal theory and tested in this paper.

${ }^{6}$ The issue of clearinghouse certificates allowed interbank settlements without the use of cash, increasing liquidity in the system.
} 
uninhabited wilderness merely to insure that another road would not claim the territory first (p.145)." The collapse in the industry was such that one quarter of "the national capitalization of American railroads were in the hands of receivers (Faukner 1959, p.142)." The plummet in railroad construction from a record setting pace to near zero and the collapse of industries, such as steel, that fed railroad growth could well have been a national shock that caused individuals nationwide to be concerned about the solvency of their banks.

The second real shock was in the silver industry. The new Presidential administration in 1893 had stated that one of its key objectives was the repeal of the Silver Purchase Law of 1890, which mandated that the government use legal-tender notes to purchase a specific quantity of silver each year. Debate over this proposition was loud and highly charged. The price of silver was volatile and rose or fell as one faction or another seemed to gain the upper hand. As it became clear that the faction supporting repeal was gaining votes the price of silver collapsed and resulted in the closing of many mines in the West (Bradstreet's 1893, Rocky Mountain Times 1893).

There are two possible explanations for the widespread nature of the crisis. The first is that the panic spread through the banking system. The partial suspension of banks in New York meant that banks in the interior lost access to some of their most liquid assets. In addition some banks in large interior cities publicly refused to honor commitments to country correspondents (Wicker 2000). As news spread about the inability of some banks to access their interbank deposits, the populace may have become concerned about their ability to access cash. The interconnectedness of the banking system would have allowed the initial suspensions to cascade into widespread bank runs.

The second explanation is that the panic could have been spread through real shocks such as the collapse of the silver industry and railway industry. In this view, bank runs resulted from depositors pulling their money from potentially insolvent banks. The fact that the silver industry was located in the West would then explain why a large portion of the bank failures and suspensions were also located in the West.

These two channels are not mutually exclusive. The panic may have spread through both channels. The panic may also have spread through different channels at different times. The Panic of 1893 was unusual in that had two phases while other crises had a single wave of failures and suspensions. The first phase of the panic, starting in June and lasting until the middle of July, began 
in the interior and spread to New York. This was unique in itself. Most crises started in New York and spread to the interior (Sprague 1910). The second phase of the panic stared in late July and lasted until the beginning of September. This phase of the panic began in New York City and spread outward, more closely resembling a "usual" panic. It is possible that the initial phase was widespread because of the large number of business failures, while the second phase was spread through financial linkages to New York.

\section{Section 3 Related Literature}

There are two classic trains of thought regarding panics. Friedman and Schwartz (1963) argue that panics are caused primarily by a loss of confidence in the banking sector, due perhaps to the failure of a large bank, or to a loss of confidence in the currency. In either case, the panic is focused on the banking sector and results in depositors withdrawing specie or other money from banks and hoarding it, resulting in a severe monetary contraction. The second train of thought, as articulated by Kindleberger (1978), is that crises are part of a boom and bust cycle that involves both the wider financial sector and the real sector. A boom occurs as the financial sector extends more and more credit to the real sector based on expectations of remarkable future growth. Over time the financial sector becomes highly leveraged. When there is a reversal of economic fortunes and borrowers are unable to repay their loans, there is a financial crisis as lenders find they lack the reserves to cover losses.

Recent theories of bank panics are more formal and narrowly tailored, but they are built on ideas from the theories presented above. This section presents two current theories of bank panics and several studies that have tested their predictions.

\section{Section 3.1 Random Withdrawal}

Diamond and Dybvig, in their seminal 1983 article, present a model in which bank runs are a rational response to beliefs possessed by rational agents. Their model is a three period model. In period zero, agents make their investment decisions. In period one, agents discover if they are first

or second period consumers. Agents have access to a two period investment project. The investment pays some return if it is followed through to completion and no return otherwise. First period consumers need to liquidate their investment in order to consume. A bank acts as a means 
of pooling risk. The bank takes deposits, invests some of the deposits in the investment projects, and holds some deposits to meet withdrawals in period one. When withdrawals occur, it is assumed to be on a first come, first serve basis. By pooling deposits, the bank is able to offer both first and second period consumers a positive return on their deposits.

Bank runs arise if a second period consumer believes that the bank is holding insufficient reserves to meet all the period one withdrawals. Failure of the bank to do so means that it would have to liquidate assets and would not have enough resources in period two to meet its obligations. In this case, the second period consumer would go to the bank in order to ensure that she is able to withdraw her deposits. If one second period consumer goes to the bank, then the other second period consumers would go to the bank in order to ensure that they are not left unable to withdraw their money in the second period. Thus, everyone would try to withdraw their funds from the bank in period one and a bank run would occur. Runs can be prevented by the threat of suspension or the introduction of deposit insurance. Because the bank run is triggered by a change in beliefs possibly due to a random signal such as "sunspots," this paper forms the basis for the random withdrawal theory.

Work following Diamond and Dybvig has further explored how depositors' beliefs about the actions of other depositors affect the likelihood of a run. Engineer (1989) extends the number of periods in the model. He shows that concern about the possibility of a bank run in the distant future could cause a bank run in the current period. $\mathrm{g}$ In this situation, the threat of suspension of deposit repayment by banks does not deter bank runs.

In their model, Diamond and Dybvig make several critical assumptions. The first is the existence of a sequential service constraint. Depositors are paid in order of arrival as long as the bank has funds. Because the last person to the bank does not receive his deposits back, there is an incentive to hurry to the bank. If instead, people are given shares of the bank's assets when the bank is liquidated, then each person would receive something and this would dramatically reduce the incentives to run the bank. The second assumption is that agents are not allowed to trade shares

\footnotetext{
7 Other signals mentioned are business failures and the suspension of other banks. Because, however, the signal could be anything, the change in beliefs would appear random.

8 There is a strong seasonal component to panics suggesting an association with crop movements. In 1893 , many suspensions occurred in late July or early August, prior to harvest season. If Engineer is correct, then the runs may have occurred because farmers were concerned that the instability would endure into the harvest season.
} 
in the bank's assets. If they are allowed to do this, then they could insure against a run. Thus, markets are assumed to be incomplete in an important way.

A popular explanation for these features has been that they occurred due to the geographic separation and structure of the banking system under the National Banking Act. Smith (1991) presents a model similar to that of Diamond and Dybvig, except that the country banks play the role of depositors and the central reserve city plays the role of the bank. This model has the advantage that it explains the sequential service constraint, why markets are incomplete, and how panics can spread nationally, encompassing more than a single bank. The geographic separation of the country banks prevents them from trading state-contingent claims on New York and from coordinating withdrawals. Thus, the central reserve city meets demands for funds as it receives them, giving rise naturally to the sequential service constraint. Panics are spread through the reserve system. If the amount that banks want to withdraw from the central reserve city in the first period is larger than expected, the central reserve city is forced to suspend. If the central reserve city suspends, some banks that are expecting to get their reserves are unable to get them. The need to access reserves and the sequential service constraint leads to panics by the country banks of a sort similar to Diamond and Dybvig runs. The key variable in Smith's model, reserves with the central reserve city, is the variable used below to test the random withdrawal model.

Chari (1989) presents a model with aggregate uncertainty about consumption needs - and thus about the size of bank withdrawals. Geographic separation prevents depositors from pooling risk, but banks could pool risk by establishing a central reserve, a structure similar to the financial structure of the National Banking Era. If future consumption needs are sufficiently great, bank runs occur because depositors and banks are concerned about being repaid in a timely manner. The sequential service constraint arises as a way of efficiently distributing resources.

\section{Section 3.2 Asymmetric Information}

According to the asymmetric information theory, depositors do not withdraw funds from the bank because of sudden needs for resources; rather they withdraw their funds because they are concerned that the bank is going to fail. Gorton (1985) argues that banks' returns are uncertain. Depositors hold bank deposits as long as the expected return on deposits is higher than the return on holding cash. With full information, depositors would know if returns on bank deposits are lower 
than the return on money. If that happens, they would withdraw their deposits and close the bank. Gorton supposes that information is not perfect; depositors receive only an imperfect signal about the returns on the bank's loans. With imperfect signals, depositors close some banks that are solvent and leave open some banks that should have been closed. The theory is considered one of asymmetric information because the banks know the quality of their loans, but the depositors do not.

Calomiris and Khan (1991) present an alternative model in which only some of the depositors receive signals. In this framework, the informed depositors receive a costly and imperfect signal about the quality of the bank. Based on this signal they decide whether to withdraw their funds from the bank. The uninformed depositors watch the lines at the bank. If they perceive that the informed depositors are withdrawing their funds, then they too withdraw their deposits. Like the random withdrawal theory, this model uses a sequential service constraint. Here, however, the sequential service constraint is part of an optimal contract. The sequential service constraint rewards informed investors for obtaining the costly signal by informing them when to get in line in order to ensure that they receive their deposits.

Others have constructed models that involve asymmetric information and self-fulfilling bank panics but do not require sequential service or incomplete markets. Chari and Jagannathan (1988) construct a model where returns to long-term investment are uncertain and only a small group of second period consumers are informed about the returns. Other second period consumers use the number of depositors trying to withdraw as a signal to guess the returns. Long lines are a signal that returns are bad. If the number of first and second period consumers, and hence expected line length, is unknown then runs could be self-fulfilling.

\section{Section 3.3 Tests of the Theories}

There have been a variety of papers that have tested aspects of these two theories. Several papers have tested whether panic environments were systemically different than other periods or whether they were the same. Since the random withdrawal theory is associated with a sudden change in beliefs, predictable panics are evidence in favor of the asymmetric information theory.

\footnotetext{
${ }^{9}$ This model is similar to the one described above by Calomiris and Kahn (1991). The primary difference is how active the uniformed depositors are.
} 
Using quarterly data, Gorton (1987) finds that consumption weighted deposit losses predict panics, supporting the asymmetric information theory. Using higher frequency weekly data on interest rates, Donaldson (1992) finds that panics are unpredictable events, lending support to the random withdrawal theory.

Mishkin (1991) examines the yield spreads between low and high risk bonds for seven financial crises between 1850 and 1910 as well as the Great Depression. He finds that yield spreads peak near the time of the panic. This is consistent with the prediction of the asymmetric information theory of increased uncertainty about the economic outlook and increased risk of business failure.

In their detailed study, Calomiris and Gorton (1991) clearly identify differences in predictions of the asymmetric information theory and the random withdrawal theory and test these differences using data from the National Banking Era. The predictions they test involve looking at the source of the panics, the location of bank closings, and the resolution of the panics.

Calomiris and Gorton focus mainly on the sources of the panics. The random withdrawal theory predicts that a panic is triggered by a change in beliefs, although what might trigger that change is not specified. This makes testing the theory based on the source of the panic very difficult. Chari (1989) argues that since panics were seasonal in nature, excessively high grain yields may have triggered the increase in demand. ${ }^{1}$ The asymmetric information theory suggests that depositors will precipitate a bank run if they receive a negative signal about the quality of the bank's loans. Thus, each panic should have been preceded by a large negative real shock. Calomiris and Gorton show that there were several years when seasonal crop yields exceed those of the panic years, indicating that this is not a likely source of the panic. On the other hand, real declines in the stock market are found to be larger in panic years than in non-panic years. This suggests that real economic events are associated with panics.

While suggestive, this evidence is not conclusive. It is possible that a shift in depositors' beliefs might be caused by something other than large harvests. If a stock market crash often led New York banks to suspend cash payments to the interior, and depositors in the interior were worried about being able to have the resources to move their harvests to market, then a collapse in

\footnotetext{
${ }^{10}$ See Miron (1986) for a discussion of the seasonal nature of panics.

${ }^{11}$ Though of course correlation does not imply causation.
} 
the stock market may have precipitated random withdrawals. It is also conceivable that there was more than one type of signal that could have changed depositors' needs for their deposits and that the signal was unique to each crisis. Lauck (1907) and Noyes (1909) suggest that the crisis of 1893 occurred because fear of an abandonment of the gold standard lead to a sudden desire by depositors to hold their wealth as specie rather than deposits.

The location of bank closings is another way to distinguish between the two theories. The random withdrawal theory predicts that bank closings will be in areas of high money demand. The asymmetric information theory predicts that bank closings will be in areas of large real asset shocks. Calomiris and Gorton show that bank failures were located in areas of real shocks and that the most common reason given for closing banks was asset depreciation. This is again evidence in favor of the asymmetric information theory; however, since neither theory predicts that banks necessarily fail during a crisis, examining failures is an imperfect test.

The two theories also have different predictions regarding the resolution of a panic. The random withdrawal theory predicts that an increase in available cash resources should bring the panic to a close. The asymmetric information theory suggests that the panic will only conclude once it can be resolved which banks are solvent and which are not. Calomiris and Gorton point out that specie could have been imported into the United States from Europe in ten days, and distributed throughout the country within a matter of a few more days. Thus, panics should only have lasted several weeks if the random withdrawal theory is correct. While the panic of 1873 and the suspension of payments in New York in the Panic of 1893 each lasted about a month, the panic of 1907 lasted for two and a half months, substantially longer than the random withdrawal theory would predict. Calomiris and Gorton take this as evidence in favor of the asymmetric information theory; however, they do not present any evidence indicating that the asymmetric theory describes the timing of the resolution of the panics of the National Banking Era.

\section{Section 4 Testing the Crisis of 1893}

The crisis of 1893 is examined in detail to see whether the events of the crisis more closely match the predictions of the asymmetric information theory or the random withdrawal theory. As suggested by Calomiris and Gorton (1991), I discuss the origin and resolution of the panic. The bulk of the analysis, however, focuses on which banks suspended: those in close proximity to real 
shocks, those that were financially weakest, or those most connected to the reserve system.

\section{Section 4.1 Beginning of the Crisis}

The asymmetric information theory suggests that real shocks should underlie the crisis, while the random withdrawal theory suggests that there should be some event that causes depositors to want to withdraw their deposits. Records of the crisis of 1893 clearly identify several commercial failures that affected the Northeast and caused the stock market to collapse (Noyes, 1909; Sprague, 1910). These same records, however, indicate that the initial bank suspensions occurred about a month after the significant commercial failures and in the South and West rather than the Northeast. Faulkner (1959) describes a national problem of railroad failures in all parts of the country. The Rocky Mountain Times describes the shutdown of many silver mines in the West. These events are most consistent with the asymmetric information theory.

The suspensions in July follow a suspension of cash payments in New York (Sprague 1910). This suspension of payments created a premium for cash and led to some cash hoarding (Noyes 1909). That the scarcity of cash and the inability of banks to access their interbank deposits resulted in suspension during the second phase of the crisis is most consistent with the Smith version of the random withdrawal theory.

\section{Section 4.2 Resolution of the Crisis}

The asymmetric information story suggests that the crisis should be resolved once banks are able to demonstrate their solvency while the random withdrawal theory suggests that the crisis should be resolved once liquidity is restored. Noyes (1909) notes that high interest rates and the premium that existed for specie attracted gold from Europe. He suggested that once these flows became large enough, the crisis was alleviated. This is suggestive of the random withdrawal theory.

\section{Section 4.3 Tests using Bank Suspensions}

\section{Section 4.3.1 Data and Methodology}

The information available on the Crisis of 1893 offers a unique opportunity to examine the causes of bank suspensions. Soon after this crisis, the Comptroller of the Currency published, in addition to a list of banks turned over to receivers, a list of the national banks that suspended and 
later reopened, the dates for which they were suspended, and the city and state in which they were located. This information is not available for the other crises of the National Banking Era. Banks that suspended and later reopened are considered to be solvent institutions that were forced to suspend due to the crisis and otherwise would not have. This follows the writings of the Comptroller who reported:

"Many banks after paying out on the one hand all the money in their vaults and failing to collect their loans on the other, suspended and passed into the hands of the Comptroller. With a full knowledge of the general solvency of these institutions and the cause which brought about their suspension, the policy was inaugurated of giving all banks, which, under general circumstances, would not have closed, and whose management had been honest, the opportunity to resume business.... In no instance has any bank been permitted to resume on money borrowed. (Report of 1893, p.10)"

Determining the reasons these banks suspended allows the two theories on bank runs to be tested. Bradstreet's also reported bank closure and suspension information for the Crisis of 1893 for all types of banks: national, state, savings, and private.

Table 1 provides information on the location of national bank failures by region and phase of the panic (whether or not New York was in suspension). Most failures and suspensions occurred in the West of the country. The Northeast was virtually unscathed in the crisis.

The Office of the Comptroller of the Currency provides a variety of balance sheet information for national banks. The Rand-McNally Bankers' Directory provides information on the correspondents, capital, surplus, and undivided profits of all banks. No other balance sheet information is available for state, savings, or private banks.

\section{Analysis Using State Level Aggregates}

The dependent variable in the state level analysis is the number of national banks in a state that suspend. The asymmetric information theory predicts that the more real shocks in a state the more banks will suspend. The random withdrawal theory predicts that the more connected the bank is to the national reserve system, the more likely the bank is to suspend.

\footnotetext{
${ }^{12}$ Banks not listed as reopened by the Nov. 11, 1893 issue of Bradstreet's are considered to be failures as further information is unavailable after this date. Comparison with the data from the comptroller of the currency suggests that this cutoff may slightly overstate the number of failures and understate the number of suspensions as some banks reopened soon after. To be as accurate as possible, most of the analysis uses the records from the Comptroller of the Currency.
} 
According to the asymmetric information theory, depositors withdraw their funds when they become concerned about the solvency of their bank. Concern about bank solvency is in turn prompted by a real shock. Real shocks can take many forms making them difficult to measure. A variety of measures are used to indicate real shocks. The first proxy for real shocks I use the number of business failures in 1892 divided by the number of manufacturing establishments existing in $1890 .^{13}$ The business failures from the year preceding the crisis provides an indication about the losses the banks have recently faced and the strength of their balance sheets; it also avoids the endogeneity problem found in using business failures in the crisis year that stems from concern that bank closings may have reduced lending to firms causing them to fail. The second indicator that a real shock has occurred is the percent change in the asset value of failed businesses between the first six months of 1892 and 1893. Both these measures of business failures provide indications about the level of stress on the banking system. The third indicator used is the number of national bank failures in the state. ${ }^{1.5}$ When a real shock occurs, a bank's assets suffer. If the shock is severe, the bank will become insolvent and be liquidated. Thus, a bank failure is a sign that a shock has occurred and is a signal to depositors that they should be concerned about the health of other banks. The theory suggests that this concern is manifested in bank runs and suspensions. Thus testing whether there is strong correlation between the location of bank suspensions and bank failures is a test of the asymmetric information theory.

Using bank failures, as an indicator of real shocks, requires the assumption that banks would suspend before the run could force sale of assets at below value prices and thus failure. As regulators did not penalize banks for suspending, this assumption is plausible. Banks may have been tempted to stay open because of the opportunity cost from being unable to conduct business while suspended and because suspending may have resulted in a stigma of being weak and a subsequent loss of depositors and future business; however, these costs are likely to have been less than the cost of failing and being out of business permanently.

\footnotetext{
${ }^{13}$ Bradstreet's published quarterly statistics on business failures, but no information on surviving businesses. The best available estimate of the number of existing businesses is the number of manufacturing establishments reported in the 1890 census.

${ }^{14} \mathrm{I}$ also test the assets and number of business failures per national bank, which give similar, though not as significant results as the share of businesses that fail. Another alternative real shock is the changes in agricultural prices weighted by crop production levels. No significant effect was found for this measure.

${ }^{15}$ Descriptions of the closure of non-national banks suggest that their closing was influenced by the closing of
} 
The random withdrawal theory suggests that bank panics were transmitted through the reserve system. The central reserve had a limited amount of liquid reserves. A few regional panics would use up all these reserves and force the central reserve to suspend payments to all other regions. This would make all the other regions much more vulnerable to bank runs. Thus, financial instability was transmitted from region to region. Under this line of reasoning, a stronger connection to the reserve system should be correlated with the number of bank suspensions. Connection with the reserve system is measured by looking at the balance sheet item "due from reserve agents". 16 Because data is not available on the share of assets state, savings, and private banks held in reserve cities, and thus on their connectedness to the reserve system, the number of bank suspensions is confined to be the number of national bank suspensions.

At the state level, this is the aggregate "due from reserve agents" for all country banks within the state. 1 There are two ways that "due from reserve agents" can be used to measure connection to New York. The first is as the fraction of liquid reserves. 18 This measures how dependent the banks were on the reserve system. The second measure is the percent change in "due from reserve agents." A large change may indicate country banks required reserves to meet withdrawal demand. The Comptroller of the Currency collected a variety of state level information on the national banks. This information was collected for the months of March, May, July, October, and December. Thus the percent change from May to July and July to October can also be used to measure how reliant the states' banks were on the national bank reserve system to meet demand.

If depositors knew that a suspension in New York meant that their bank would be unable to access its reserves, the suspension in New York could itself provoke a bank run. It is quite reasonable that people understood that their bank was affected by a suspension in New York. During the two decades prior to the Panic of 1893, there had been three financial crises, each associated with suspensions in New York. Banks were also quite public about their interactions with their correspondents and their ability/inability to transfer money to and from New York. Noyes (1909) confirms that people knew a suspension in New York could cause financial

\footnotetext{
national banks rather than the other way around.

16 "Due from reserve agents" is distinct from the other balance sheet items related to interbank deposits such as "Due from National Banks" and "Due from State Banks."

${ }^{17}$ In the reports, statistics for reserve cities in the state are reported separately.
} 
difficulties for their bank.

The fact that the panic consisted of a period without a suspension in New York and a period when New York was in suspension provides a unique opportunity to test the random withdrawal theory. When New York is not in suspension, banks can freely access their reserves so there should be no negative effect of holding reserves there. When New York is in suspension, banks cannot access their reserves and their vulnerability to bank runs increases and is therefore the means by which the crisis becomes nationwide. The random withdrawal theory implies there should be a difference in the reason for suspension between the period when New York is suspended and the period when it is not, especially in the importance of reserves "due from reserve agents."

It is important to note that predictions about the measures used in this analysis may overlap. A bank failure may provide a signal to depositors in the random withdrawal theory to change their beliefs about whether other depositors will run the bank and a lack of liquidity increases the probability of suspension in the asymmetric information theory. However, the real shock causing the bank failure is necessary for the asymmetric information but is only a possible factor for the random withdrawal theory. The impact of each bank's connection to the reserve system is necessary for contagion in the random withdrawal theory, but is only a potentially aggravating factor in the asymmetric information theory. Thus, finding that neither bank failures nor "due from reserve agents" matters is inconsistent with both theories, finding that only one factor matters is evidence in favor of a particular theory, and finding that both bank failures and reserves matter is consistent with both theories separately and together and is inconclusive.

At the state level, the number of banks suspending can only take on whole numbered values. Therefore, the appropriate analysis technique is count data analysis. This technique analyzes the number of times an event occurs in different groups, here the different states. Often the population of each group is the same, whereas in this paper, that is not the case. Different states have quite different numbers of banks at risk, so the population of banks in each state must be taken into account. Cameron and Trivedi (1998) indicate that the appropriate way to account for this is to impose the restriction that the effect of the log of the population is equal to one. This procedure,

\footnotetext{
${ }^{18}$ Liquid reserves are taken as the sum of due from national banks, notes, specie, and stocks.

${ }^{19}$ The minimum number of banks is 5 and the maximum is 325 .
} 
however, makes it difficult to provide an economic interpretation of the results. During the state level analysis, the 48 contiguous states and territories are used.

Because the city location is given, it is also possible to determine whether the banks are country banks or reserve city banks. Reserve city banks, because of their intermediary role, may be subject to different pressures than country banks and are not included in the analysis.

The crisis is considered to extend from the beginning of June until the end of August. Only three banks suspended during 1893 prior to June and no banks suspended after August.

To summarize, the asymmetric information theory will be tested by examining whether national bank failures or business failures are correlated with bank suspensions and the random withdrawal theory will be tested by observing whether share of reserves composed of "due from reserve agents" and the percent change in "due from reserve agents" are associated with bank suspensions. A further test of the random withdrawal theory will be whether "due from reserves agents" has the same impact whether or not the New York Clearinghouse has suspended.

\section{Analysis of Individual National Banks}

The two theories of banks panics are tested using individual bank data as well. A series of tests are conducted to determine whether a variety of factors affected whether a non-failure bank suspended or not.

The asymmetric information theory is again tested using national bank failures to represent real shocks. For this level of analysis, I test whether proximity to a bank failure made a bank more likely to suspend. Proximity is measured as the log of the distance between each bank and the nearest failing bank.

Likewise, to test the random withdrawal theory, I again use "due from reserve agents". Here however this measure can only be used as the share of liquid reserves and not the percent change, because balance sheet data for individual banks is only available on an annual basis.

Again the sample can be broken into two parts: when New York was open and when it was in suspension. Banks in the second period are those that survived the first period. Again the random withdrawal theory predicts a different impact of "due from reserve agents" when New York

\footnotetext{
${ }^{20}$ Failed banks were dropped from the sample.

${ }^{21}$ The distance in miles between banks and the nearest same state failure was determined for each bank.
} 
suspends.

Analysis of individual banks offers an additional test of the asymmetric information theory. Not all banks were targets of runs. For depositors to discriminate, the asymmetric information theory suggests that banks that suffered a run and were forced to suspend should in some ways resemble failing banks more than banks that stayed open. The test is then to estimate the probability of survival (here banks that did not suspend versus failing banks) based on balance sheet characteristics, for the failing and non-suspending banks. Based on the effects of balance sheet characteristics survival probabilities for suspending banks are calculated. The asymmetric information theory indicates that these probabilities should differ between suspending and nonsuspending banks.

The individual national bank analysis employs data from Colorado, Montana, Oregon and Washington. These states were selected because they had high numbers of suspensions and failures. The use of individual bank data also allows a variety of bank fundamentals to be controlled for in the analysis. These fundamentals come from the balance sheet data in the Annual Report of the Comptroller of the Currency. The balance sheet information collected closest to the start of the panic is for October 1892. Table 2 provides a list of bank suspensions and failures for the four states examined.

\section{Analysis of Colorado}

Colorado, the nation's leading silver producer, was especially hard hit by the plummeting price of silver. During the crisis period a number of banks failed - 1 National, 5 State, 3 Savings, and 5 Private banks. There were also a large number of suspensions (23), especially in Denver, which experienced a large bank panic. The local Denver newspaper, the Rocky Mountain Times, provides an excellent narrative of the panic. Facts about the crisis, as chronicled in the Rocky Mountain Times, are presented and discussed in relation to the two theories. Information from the Rocky Mountain Times, Bradstreet's, and the Rand-McNally Bankers' Directory, regarding all Colorado Banks, is also collected and examined for patterns.

\section{Section 4.3.2 Results of State Level Analysis}

The first test regresses the total number of suspensions in a state during the crisis on real 
shock indicators, the May value of the share of reserves in total assets, and the share of "due from reserve agents" in reserves. Results are in Table 3.

The results are most consistent with the asymmetric information theory. Two of the three measures of real shocks indicate that the larger the real shock, the larger the number of suspensions as predicted by the asymmetric information theory. The third measure has the predicted sign, but is not significant. No evidence is found that banks were forced to suspend because of their connections with the reserve system as predicted by the random withdrawal hypothesis.

The analysis used above assumes that the number of bank suspensions follows a Poisson process. This process imposes strong assumptions on the distribution of the data. This assumption can be relaxed by assuming that the data follows a negative binomial process, a more general process of which the Poisson process is a special case. Table 3 also presents test results using the negative binomial process. A likelihood-ratio test fails to reject that the two sets of results are identical indicating that the results using the Poisson distribution are correct.

Next, I test whether the suspension in New York marked a change in the cause of the panic, especially in the predictive power of assets with reserve agents. The sample is divided into two periods, which are then combined. ${ }^{24}$ The analysis is conducted using the same explanatory variables as above and using the percent change in reserves. Because the analysis focuses on the random withdrawal theory and whether New York suspended, I present only the results using the failures of banks as an indicator of real shocks. Results are similar regardless of which indicator is used, however the number of failed banks provides the best fit because, unlike the other indicators, the number of bank failures in each phase can be identified. All explanatory variables are interacted with a dummy indicating New York is in suspension. This allows individual and joint tests of the effects of a suspension in New York. Table 4 presents results of this exercise.

No evidence is found that a suspension in New York affects the importance of reserves held there, or any of the other explanatory variables. This is contrary to the predictions of the random withdrawal theory. Bank failures are found to be an effective predictor of bank suspensions in both periods, again supporting the asymmetric information hypothesis.

\footnotetext{
${ }^{22}$ Specifically that the conditional mean of the data equals the conditional variance.

${ }^{23}$ Throughout the state level analysis I am unable to reject that the Poisson and negative binomial results are identical, indicating that the choice of distribution does not affect the results.

${ }^{24}$ Test results indicate that this does not place excessive restrictions on the error term.
} 


\section{Section 4.3.3 Individual Bank Analysis Results}

The first test is simply whether bank fundamentals, proximity to a bank failure, and connection to the reserves system of the National Banking Era affected the likelihood that a nonfailing bank suspended. The results appear in Table 5. A positive number indicates that the variable increases the likelihood of survival while a negative number indicates that the variable increases the likelihood of suspension. (So the results indicate that an increase in net worth relative to assets increases the likelihood of survival.)

Neither the variable suggested by the asymmetric theory (distance to failure) nor the variable suggested by the random withdrawal theory (deposits with reserve agents) has any affect on bank survival. A variation of the distance variable, being in the same city as a failed bank, is included in the analysis. Like the log of the distance, this variable is unrelated to the likelihood of suspension. Thus no support is found for either theory.

Another test of the random withdrawal theory is whether the suspension in New York had any affect at the individual bank level. The above analysis is repeated for the period when New York was open and the period when it had suspended. The dependent variable is whether the bank suspended in a particular period. Banks that suspended during the first period are not included in the analysis of the second period because they are not "at risk." The results are in Table 6.

There is no observable effect of a suspension in New York. Effects of the explanatory variables have similar magnitudes and levels of significance. Formal testing of differences is conducted in Column 3 in which the samples are pooled and the explanatory variables are interacted with a dummy for suspension in New York. Neither individual not joint significance tests reveal any evidence that a suspension in New York affected the suspension of country banks. Thus the prediction of the random withdrawal theory does not hold.

A second test of the asymmetric information theory is whether banks that suspended more closely resembled banks that did not suspend or banks that failed. The balance sheet characteristics used above are tested to see whether they affected the probability that a bank failed or remained open (suspending banks are temporarily dropped from the sample). Based on the effects of these characteristics the likelihood of bank failure, bank survival probabilities are calculated for all three types of banks (failing, suspending, and remaining open). The mean survival probability can then 
be calculated for each group and compared. ${ }^{6}$ Suspending banks (mean survival probability $=0.86$, s.d. $=0.11$ ) are indistinguishable from banks remaining open (mean survival probability $=0.89$, s.d. $=0.11$ ) and significantly different from failing banks (mean survival probability $=0.76$, s.d. $=0.16$ ). This is contrary to the predictions of the asymmetric information theory.

\section{Section 4.3.4 Analysis of Colorado}

On July $18^{\text {th }}$ Denver was swept by a bank panic. The panic began as four savings banks closed their doors, three permanently. These banks had been the subjects of a previous run which they had forestalled by enforcing a 60 day waiting period on withdrawals. Those 60 days expired on July $17^{\text {th }}$. Soon the savings banks closed and runs began on several national banks. Some closed that day, while others simply did not reopen the next. By the time the panic subsided, six national banks and several other banks were forced to close.

The Rocky Mountain Times (RMT), the local Denver newspaper, closely followed the events. Here several items about the crisis are reported and analyzed in relation to the two theories. Extreme care has been taken to separate out the facts as the RMT tended to editorialize in its articles.

Item 1: Only certain banks were targeted, others were the recipients of deposit inflows. The banks targeted during the runs seem to be the weak ones. (Three of the six closed national banks had seen large declines in deposits over the previous three months).

This is consistent with the Asymmetric Information theory, which suggests that if certain banks are to be targeted, it will be the weakest ones, about whom there is the most concern about failure.

Item 2: Runs were primarily by small "uninformed” depositors.

This is most consistent with the asymmetric information theory, especially in connection with

\footnotetext{
${ }^{25}$ This exercise is similar to the one conducted by Calomiris and Mason (1997) using time to failure analysis. They tested whether banks that failed in the Chicago panic of 1932 more closely resembled survivors of the panic or banks that failed outside the panic period. This exercise compares banks that suspended during the panic to banks that failed during the panic and banks that remained open during the panic.

${ }^{26}$ Depositors engaged in the earlier runs on savings banks were referred to as "pick-pockets and hold-ups".

${ }^{27}$ Though apparently for one bank this was not well known as the paper expressed surprise and reported the decline in deposits several days after the panic.
} 
Item 1. Several versions of the asymmetric theory suggest that large depositors have an incentive to keep a careful watch on the quality and withdraw once they perceive a problem. Small depositors may use this as a signal that the bank is weak. Thus previous declines in deposits were due to "informed" depositors withdrawing their money and the runs were by small "uninformed" depositors.

Item 3: Banks runs were expected and banks responded by stockpiling cash. National banks that stayed open had amassed huge cash reserves $\sim 80 \%$ of liquid deposits.

This is consistent with both theories, though perhaps more so with the random withdrawal theory. Under the random withdrawal theory, depositors run banks because they are concerned that the bank has insufficient liquid assets to meet demand. A way to forestall runs then is to stockpile liquid assets (cash) and place it on display (as many bank did).

Displaying cash may also be a way of demonstrating solvency so that this item is also consistent with the asymmetric information theory. There are, however, other, more efficient, ways of demonstrating asset quality, such as independent certification, which were not used until after the runs occurred. (After the runs, respected citizens were brought in to check the books and assure the public the bank had the resources to cover deposits.)

Item 4: Fear about deposit accessibility causes runs to spread. "The run on this bank was started by the closing of the savings banks the day before, which tied up the available funds of a large number of working people. This alarmed many others, thus creating a feeling of panic (RMT July 19, 1893 p.2, column 3).”

This is most consistent with the random withdrawal theory, where depositors run banks because they are concerned that the banks may not have sufficient liquid assets on hand to meet demand. It is possible that the closing of savings banks provided evidence that a real shock had occurred, however, this is unlikely since the initial run on these banks was 60 days prior and it was only after the 60 days waiting period that the savings banks closed. Thus, the informational content was two months out of date. The savings banks are also described as being small and unaffiliated with the national banks making it unclear why their closing provided informational content about the national banks that were forced to suspend. 


\section{Outside Denver}

An examination of the banks outside Denver and Pueblo, as well as suspending nonnational banks within Denver suggests a pattern in the suspensions that occurred. ${ }^{28}$ Nearly all (9 out of 12) these suspending banks had correspondent relationships with a bank in Denver that suspended (Rand-McNally, Rocky Mountain Times). Correspondent relationships were a way that banks cleared checks and offered services to depositors. The loss of a correspondent thus deprived banks of a way of obtaining funds from non-local checks presented to them. Thus if cash balances were already low, banks may have been forced to suspend. Concerned depositors may have increased withdrawals, fearing insufficient liquid assets on the part of banks. Depositors may also have feared that this loss of ability to conduct business may have harmed banks' profitability. Thus if correspondent networks did cause financial instability to spread, it is unclear whether it can be attributed to the random withdrawal theory, the asymmetric information theory, or simply a disruption in the payment system.

The effect of correspondent networks is suggestive but not conclusive. Of the 118 banks outside Denver/Pueblo, 12 suspended. Most banks (81) either did not have correspondents in Denver/Pueblo or else their correspondents remained open, only 3 of these banks suspended. Of

the remaining 37 banks that did have a suspending correspondent, 9 suspended. Thus a correspondent relationship may have increased the odds of suspension but did not necessarily trigger a suspension. More work will need to be done to further examine whether correspondent networks actually served to transmit financial instability.

\section{Section 5 Conclusion}

The different levels of analysis conducted above contain disparate findings. The evidence from state level aggregate data suggests that runs take place in areas that have been subjected to economic shocks, as predicted by the asymmetric information theory. The evidence based on analysis of balance sheet data of individual national banks provides little evidence to support either theory. Analysis of banks throughout the state of Colorado suggest that correspondent banking provided a means by which panics could be transmitted but not the reason why correspondent networks acted as a channel. The historical record of panics in Denver suggests that runs proceeded 
in a manner similar to that described by the asymmetric information literature, but that the reasons have as much to do with the liquidity of banks and the ability of depositors to have timely access to their deposits as they have to do with the solvency of the banks. Thus, there is some support for both theories, although more for the asymmetric information theory.

While basing any conclusions on a single panic episode is tenuous, the description of the Denver crisis does suggest a coherent explanation that incorporates ideas from both theories and builds on all the facts. It may be that depositors panic because they are concerned that they will be unable to access their deposits either because the bank is illiquid (random withdrawal) or because the bank is insolvent (asymmetric information). These concerns, however, do not arise ex nihilo. Concerns that there may be widespread financial instability are only credible after there has been a large negative real economic shock. Once there is uncertainty about financial stability, a shock that indicates to depositors that they may lose their ability to access their deposits in a timely manner, such as the suspension or failure of another bank, can generate a panic. Again, this hypothesis is tentative and more work will need to be done to investigate its merits.

${ }^{28}$ Pueblo suffered a minor bank panic in early July, about two weeks before the one in Denver. 


\section{References}

Bordo, Michael, Peter Rappoport, \& Anna Schwartz (1991). "Money Versus Credit Rationing: Evidence for the National Banking Era, 1880-1914," NBER Working Papers Series, April.

Bradstreet's, New York, various issues, January - December 1893.

Calomiris, Charles, and Gary Gorton (1991). "The Origins of Banking Panics: Models, Facts, and Bank Regulation," in Glenn Hubbard (ed.) Financial Markets and Einancial Crises, Chicago: University of Chicago Press.

Calomiris, Charles and Charles Khan (1991). "The Role of Demandable Debt in Structuring Optimal Banking Arrangements," American Economic Review. Vol. 81.

Calomiris, Charles \& Joseph Mason (1997). "Contagion and Bank Failures During the Great Depression: The June 1932 Chicago Banking Panic," American Economic Review. Vol. 87, pp. 863-83.

Cameron and Trivedi (1998). Regression Analysis of Count Data. Cambridge University Press, Cambridge, United Kingdom.

Chari, V.V. (1989). "Banking Without Deposit Insurance or Bank Panics: Lessons from a Model of the U.S. National Banking System," Eederal Reserve Bank of Minneapolis, Quarterly Review (Summer) pp.3-19.

Chari, V.V. and Ravi Jagannathan (1988). "Banking Panics, Information, and Rational Expectations Equilibrium," Lournal of Finance, Vol. 43, pp.749-760.

Comptroller of the Currency. Annual Report (1893). Washington D.C., United States Government Printing Office.

Diamond, Douglas and Peter Dybvig (1983). "Bank Runs, Deposit Insurance, \& Liquidity," Lournal of Political Economy 91:3.

Donaldson, R. Glen (1992). "Sources of Panics, Evidence from the Weekly Data," Lournal of Monetary Economics, Vol. 29; pp. 277-305.

Dun's Review, New York, various issues, 1893.

Engineer, Merwan (1989). "Bank Runs and the Suspension of Deposit Convertability," Journal of Monetary Economics, Vol. 24, pp.443-454. 
Faulkner, Harold (1959). Politics Reform and Expansion, Harper \& Brothers, New York.

Friedman, Milton and Anna Schwartz (1963). A Monetary History of the United States, 1867-1960, Princeton University Press, Princeton.

Glick, Reuven and Andrew Rose (1998). "Contagion and Trade: Why are Currency Crises Regional," Pacific Basin Working Paper Series, PB98-03.

Gorton, Gary (1985). "Bank Suspension of Convertability," Journal of Monetary Economics, Vol. 15, pp.177-193.

Kemmerer, Edwin (1910). Seasonal Variations in the Relative Demand for Money and Capital in the United States. United States Government Printing Office, Washington, D.C.

Kindleberger, Charles (1978). Manias, Panics, and Crashes, Basic Books, New York.

Lauck, W. Jett (1907). The Causes of the Panic of 1893, Houghton, Mifflin and Company, New York.

Miron, Jeffery (1986). "Financial Panics, the Seasonality of the Nominal Interest Rate, and the Founding of the Fed," American Economic Review, Vol. 76, pp. 125-140.

Mishkin, Frederick (1991). “Asymmetric Information and Financial Crises: A Historical Perspective," in Glenn Hubbard (ed.) Financial Markets and Financial Crises, Chicago: University of Chicago Press.

Noyes, Alexander (1909). Eorty Years of American Finance, G.P. Putnam's Sons, New York.

Radalet, Steven and Jeffrey Sachs (1998). "The Onset of the East Asian Financial Crisis," Cambridge, MA: Harvard Institute for International Development, presented at National Bureau of Economic Research Currency Crises Conference.

Rand-McNally (1893) The Bankers' Directory and List of Bank Attorneys. Rand-McNally Corporation, Chicago.

Rocky Mountain Times (May 1893-August 1893). Denver, Colorado.

Smith, Bruce (1987) "Bank Panics, Suspensions, and Geography: Some Notes on the Contagion of Fear in Banking," Economic Inquiry, Vol. XXIX, April 1991, pp. 230-248. 
Sprague, OMW (1910). History of Crises Under the National Banking System, Augustus M Kelley Publishers NY, 1968. (United States Government Printing Office, 1910).

Wicker, Elmus (2000). Banking Panics of the Gilded Age, Cambridge University Press, Cambridge, United Kingdom. 
Table 1

Location of National Bank Failures and Suspensions

\begin{tabular}{|c|c|c|c|c|}
\hline $\begin{array}{c}\text { Average Number } \\
\text { per State }\end{array}$ & Region 1 & Region 2 & Region 3 & Region 4 \\
\hline \multicolumn{5}{|l|}{ Overall } \\
\hline Banks & $\begin{array}{l}117.5 \\
(101)\end{array}$ & $\begin{array}{l}43.7 \\
(58)\end{array}$ & $\begin{array}{c}124.2 \\
(54)\end{array}$ & $\begin{array}{l}26.6 \\
(20)\end{array}$ \\
\hline Failures & $\begin{array}{c}0.2 \\
(0.6) \\
\end{array}$ & $\begin{array}{c}0.7 \\
(1.1) \\
\end{array}$ & $\begin{array}{c}0.7 \\
(0.8) \\
\end{array}$ & $\begin{array}{c}1.4 \\
(2.3) \\
\end{array}$ \\
\hline Suspensions & $\begin{array}{c}0 \\
(0.0)\end{array}$ & $\begin{array}{c}1.0 \\
(1.7)\end{array}$ & $\begin{array}{c}2.6 \\
(1.8)\end{array}$ & $\begin{array}{c}2.5 \\
(3.8)\end{array}$ \\
\hline \multicolumn{5}{|l|}{ Phase 1} \\
\hline Failures & $\begin{array}{c}0 \\
(0.0)\end{array}$ & $\begin{array}{c}0.2 \\
(0.4)\end{array}$ & $\begin{array}{c}0.5 \\
(0.7)\end{array}$ & $\begin{array}{c}1 \\
(1.6)\end{array}$ \\
\hline Suspensions & $\begin{array}{c}0 \\
(0.0) \\
\end{array}$ & $\begin{array}{c}0.4 \\
(0.9) \\
\end{array}$ & $\begin{array}{c}0.8 \\
(0.9) \\
\end{array}$ & $\begin{array}{r}1.9 \\
(3.8) \\
\end{array}$ \\
\hline \multicolumn{5}{|l|}{ Phase 2} \\
\hline Failures & $\begin{array}{c}0.2 \\
(0.6) \\
\end{array}$ & $\begin{array}{c}0.5 \\
(0.9) \\
\end{array}$ & $\begin{array}{c}0.2 \\
(0.4) \\
\end{array}$ & $\begin{array}{c}0.6 \\
(1.4) \\
\end{array}$ \\
\hline Suspensions & $\begin{array}{c}0 \\
(0.0) \\
\end{array}$ & $\begin{array}{c}0.6 \\
(1.0)\end{array}$ & $\begin{array}{c}1.7 \\
(1.7) \\
\end{array}$ & $\begin{array}{c}0.6 \\
(1.2)\end{array}$ \\
\hline
\end{tabular}

Standard deviations in parenthesis

Region 1: Connecticut, Delaware, Maine, Maryland, Massachusetts, New Hampshire, New Jersey, New York, Pennsylvania, Rhode Island, Vermont

Region 2: Alabama, Arkansas, Florida, Georgia, Kentucky, Louisiana, Mississippi, North Carolina,

Tennessee, Texas, South Carolina, Virginia, West Virginia,

Region 3: Illinois, Indiana, Iowa, Kansas, Michigan, Minnesota, Missouri, Nebraska, Ohio, Wisconsin Region 4: Arizona, California, Colorado, Idaho, Montana, Nevada, New Mexico, North Dakota,

Oklahoma, Oregon, South Dakota, Utah, Washington, Wyoming 
Table 2

Suspension and Failures in Colorado, Montana, Oregon, and Washington

Suspensions

Failures

\begin{tabular}{ll}
\hline Colorado & \\
First National, Rico & June 30 \\
First National, Ouray & July 1 \\
American National, Leadville & July 3 \\
Central National, Pueblo & July 5 \\
American National, Pueblo & July 5 \\
Western National, Pueblo & July 5 \\
Union National, Denver & July 17 \\
Bank of Commerce, Denver & July 18 \\
State National, Denver & July 19 \\
German National, Denver & July 19 \\
People's National, Denver & July 19 \\
First National, Canon City & July 20 \\
Greeley National, Greeley & July 20 \\
First National, Grand Junction & July 20
\end{tabular}

Montana

Bozeman National, Bozeman

Jul 19

National Park, Livingston

July 27

Commercial National, Denver

July 18

July 19

July 19

July 20

July 20

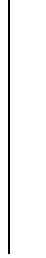


Table 3

Count Analysis of Bank Suspensions

Dependent Variable: Number suspensions per state divided by the log of the number of banks in the state

\begin{tabular}{|c|c|c|c|}
\hline Poisson & Specification 1 & Specification 2 & Specification 3 \\
\hline Bank Failures & & & $\begin{array}{c}0.22 * * \\
(0.08)\end{array}$ \\
\hline $\begin{array}{l}\text { Percent Change in Assets of } \\
\text { Business Failures }\end{array}$ & & $\begin{array}{c}0.06 \\
(0.05)\end{array}$ & \\
\hline $\begin{array}{l}\text { Fraction of Businesses } \\
\text { Failing in } 1892\end{array}$ & $\begin{array}{c}10.26^{* *} \\
(4.20)\end{array}$ & & \\
\hline $\begin{array}{l}\text { Share of reserves as "Due } \\
\text { From Reserve Agents" }\end{array}$ & $\begin{array}{c}1.50 \\
(1.72) \\
\end{array}$ & $\begin{array}{c}0.26 \\
(1.66) \\
\end{array}$ & $\begin{array}{c}0.37 \\
(1.51) \\
\end{array}$ \\
\hline $\begin{array}{l}\text { Share of reserves in total } \\
\text { assets }\end{array}$ & $\begin{array}{r}3.31 \\
(6.72) \\
\end{array}$ & $\begin{array}{r}1.02 \\
(4.39) \\
\end{array}$ & $\begin{array}{r}3.50 \\
(4.27) \\
\end{array}$ \\
\hline Constant & $\begin{array}{l}-2.63 \\
(1.63)\end{array}$ & $\begin{array}{l}-1.35 \\
(1.15)\end{array}$ & $\begin{array}{l}-2.00 * \\
(1.12)\end{array}$ \\
\hline Number Observations & 44 & 47 & 48 \\
\hline Number of Suspensions & 71 & 73 & 73 \\
\hline Number of Failures & 37 & 38 & 40 \\
\hline Log Likelihood & -32.0 & -35.7 & -34.4 \\
\hline Negative Binomial & Specification 1 & Specification 2 & Specification 3 \\
\hline Bank Failures & & & $\begin{array}{c}0.22 * * \\
(0.09) \\
\end{array}$ \\
\hline $\begin{array}{l}\text { Percent Change in Business } \\
\text { Failures }\end{array}$ & & $\begin{array}{c}0.06 \\
(0.05)\end{array}$ & \\
\hline $\begin{array}{l}\text { Fraction of Businesses } \\
\text { Failing in } 1892\end{array}$ & $\begin{array}{c}10.29 * * \\
(4.25)\end{array}$ & & \\
\hline $\begin{array}{l}\text { Share of reserves as "Due } \\
\text { From Reserve Agents" }\end{array}$ & $\begin{array}{c}1.50 \\
(1.73)\end{array}$ & $\begin{array}{c}0.26 \\
(1.66)\end{array}$ & $\begin{array}{c}0.36 \\
(1.51)\end{array}$ \\
\hline $\begin{array}{l}\text { Share of reserves in total } \\
\text { assets }\end{array}$ & $\begin{array}{c}3.31 \\
(6.75)\end{array}$ & $\begin{array}{c}1.02 \\
(4.39)\end{array}$ & $\begin{array}{c}3.50 \\
(4.27)\end{array}$ \\
\hline Constant & $\begin{array}{l}-2.63 \\
(1.63) \\
\end{array}$ & $\begin{array}{l}-1.35 \\
(1.15) \\
\end{array}$ & $\begin{array}{l}-2.00 * \\
(1.12) \\
\end{array}$ \\
\hline Dispersion & 0.0131 & 0.0011 & 0.0008 \\
\hline Number Observations & 44 & 47 & 48 \\
\hline Number of Suspensions & 71 & 73 & 73 \\
\hline Number of Failures & 37 & 38 & 40 \\
\hline Log Likelihood & -32.0 & -35.7 & -34.4 \\
\hline $\begin{array}{l}\text { Likelihood Ratio Test } \\
\text { different than Poisson }\end{array}$ & -0.02 & -0.00 & -0.00 \\
\hline
\end{tabular}

Standard errors in parentheses

* - indicates significant at $10 \%$ level

** - indicates significant at $5 \%$ level

*** - indicates significant at $1 \%$ level 
Table 4

Effect of a Suspension in New York on the Relevance of Reserves

Dependent Variable: Number suspensions per state per phase divided by the log of the number banks in the state

\begin{tabular}{|c|c|c|}
\hline & $\begin{array}{c}\text { Interbank Deposits as a } \\
\text { Share of Reserves }\end{array}$ & $\begin{array}{l}\text { Percent Change in } \\
\text { Interbank Deposits }\end{array}$ \\
\hline Bank Failures & $\begin{array}{c}0.483 * * * \\
(0.17)\end{array}$ & $\begin{array}{c}0.365^{* *} \\
(0.15)\end{array}$ \\
\hline $\begin{array}{l}\text { Bank Failures * New York in } \\
\text { Suspension }\end{array}$ & $\begin{array}{r}-0.025 \\
(0.34) \\
\end{array}$ & $\begin{array}{l}0.062 \\
(0.32) \\
\end{array}$ \\
\hline $\begin{array}{l}\text { Share of Reserves as "Due } \\
\text { From Reserve Agents" }\end{array}$ & $\begin{array}{l}1.665 \\
(2.41) \\
\end{array}$ & \\
\hline $\begin{array}{l}\text { Share "Due From" * New York } \\
\text { in Suspension }\end{array}$ & $\begin{array}{l}-1.15 \\
(4.13)\end{array}$ & \\
\hline $\begin{array}{l}\text { Share of Reserves in Total } \\
\text { Assets }\end{array}$ & $\begin{array}{l}7.407 * \\
(4.45)\end{array}$ & \\
\hline $\begin{array}{l}\text { Share of Reserves * New York } \\
\text { in Suspension }\end{array}$ & $\begin{array}{l}-6.39 \\
(9.48)\end{array}$ & \\
\hline $\begin{array}{l}\text { Percent Change in "Due From } \\
\text { Reserve Agents" }\end{array}$ & & $\begin{array}{l}-2.713 \\
(2.70) \\
\end{array}$ \\
\hline $\begin{array}{l}\text { Percent Change * New York in } \\
\text { Suspension }\end{array}$ & & $\begin{array}{l}2.570 \\
(2.84) \\
\end{array}$ \\
\hline New York in Suspension & $\begin{array}{l}1.386 \\
(2.70) \\
\end{array}$ & $\begin{array}{l}0.143 \\
(0.72) \\
\end{array}$ \\
\hline Constant & $\begin{array}{c}-3.814 * * \\
(1.52)\end{array}$ & $\begin{array}{c}-2.215 * * * \\
(0.58)\end{array}$ \\
\hline $\begin{array}{l}\mathrm{Chi}^{2} \text { Statistic that all } \\
\text { Interactions are Zero } \\
\left(\mathrm{Prob}>\mathrm{Chi}^{2}\right)\end{array}$ & $\begin{array}{c}0.51 \\
(0.91)\end{array}$ & $\begin{array}{c}0.83 \\
(0.66)\end{array}$ \\
\hline Number Observations & 96 & 96 \\
\hline Number of Suspensions & 73 & 73 \\
\hline Number of Failures & 40 & 40 \\
\hline Log Likelihood & -44.8 & -44.8 \\
\hline
\end{tabular}

Standard errors in parentheses except tests

* - indicates significant at $10 \%$ level

$* *$ - indicates significant at $5 \%$ level

*** - indicates significant at $1 \%$ level 
Table 5

Analysis of Individual Banks

\begin{tabular}{|l|c|c|c|}
\hline & Specification 1 & Specification 2 & Specification 3 \\
\hline Deposits with Reserve & 0.56 & 0.66 & 0.73 \\
Agents to Reserves & $(1.54)$ & $(1.56)$ & $(1.57)$ \\
\hline Reserves to Total Assets & 0.92 & 1.23 & 1.08 \\
& $(4.14)$ & $(4.12)$ & $(4.16)$ \\
\hline Log of the Distance to & 0.05 & & -0.26 \\
Closest Failure & $(0.15)$ & & $(0.37)$ \\
\hline Dummy for in Same City as & & -0.43 & -1.52 \\
a Bank Failure & & $(0.66)$ & $(1.70)$ \\
\hline Ratio of Net Worth to & $4.90 *$ & $5.06 *$ & $5.23 *$ \\
Assets & $(2.95)$ & $(2.98)$ & $-3.68)$ \\
\hline Ratio Loans to Assets & -3.67 & -3.61 & $(3.32)$ \\
\hline Log Total Assets & $(3.33)$ & -0.46 & -0.45 \\
\hline Constant & -0.48 & $(0.33)$ & $(0.32)$ \\
\hline & $(0.32)$ & 4.65 & 5.66 \\
\hline Number of Observations & 4.69 & $(3.46)$ & \\
\hline
\end{tabular}

A negative number implies the variable increases the likelihood of suspension

Standard errors in parentheses

* - indicates significant at $10 \%$ level

** - indicates significant at $5 \%$ level

$* * *$ - indicates significant at $1 \%$ level 
Table 6

Analysis of the Effect of Suspension in New York on Individual Banks

\begin{tabular}{|c|c|c|c|}
\hline & $\begin{array}{l}\text { New York not in } \\
\text { Suspension }\end{array}$ & $\begin{array}{l}\text { New York is } \\
\text { Suspension }\end{array}$ & Pooled Sample \\
\hline $\begin{array}{l}\text { Deposits with Reserve } \\
\text { Agents to Reserves }\end{array}$ & $\begin{array}{c}0.15 \\
(1.90) \\
\end{array}$ & $\begin{array}{c}1.71 \\
(2.50) \\
\end{array}$ & $\begin{array}{c}0.16 \\
(1.90)\end{array}$ \\
\hline $\begin{array}{l}\text { Interaction of Above with } \\
\text { New York in Suspension }\end{array}$ & & & $\begin{array}{c}1.56 \\
(3.15) \\
\end{array}$ \\
\hline Reserves to Total Assets & $\begin{array}{c}1.87 \\
(5.07)\end{array}$ & $\begin{array}{l}-0.36 \\
(6.49)\end{array}$ & $\begin{array}{c}2.05 \\
(4.74)\end{array}$ \\
\hline $\begin{array}{l}\text { Interaction of Above with } \\
\text { New York in Suspension }\end{array}$ & & & $\begin{array}{l}-2.73 \\
(6.85) \\
\end{array}$ \\
\hline $\begin{array}{l}\text { Inverse of Log of the } \\
\text { Distance }\end{array}$ & $\begin{array}{l}-0.31 \\
(0.48) \\
\end{array}$ & $\begin{array}{l}-0.18 \\
(0.53) \\
\end{array}$ & $\begin{array}{l}-0.29 \\
(0.46) \\
\end{array}$ \\
\hline $\begin{array}{l}\text { Interaction of Above with } \\
\text { New York in Suspension }\end{array}$ & & & $\begin{array}{c}0.09 \\
(0.65)\end{array}$ \\
\hline $\begin{array}{l}\text { Dummy for in Same City as } \\
\text { a Bank Failure }\end{array}$ & $\begin{array}{l}-1.59 \\
(2.16)\end{array}$ & $\begin{array}{l}-1.48 \\
(2.54)\end{array}$ & $\begin{array}{l}-1.54 \\
(2.11)\end{array}$ \\
\hline $\begin{array}{l}\text { Interaction of Above with } \\
\text { New York in Suspension }\end{array}$ & & & $\begin{array}{l}0.003 \\
(3.19)\end{array}$ \\
\hline $\begin{array}{l}\text { Ratio of Net Worth to } \\
\text { Assets }\end{array}$ & $\begin{array}{c}6.09 \\
(3.92)\end{array}$ & $\begin{array}{c}3.83 \\
(4.19)\end{array}$ & $\begin{array}{l}6.22^{*} \\
(3.73)\end{array}$ \\
\hline $\begin{array}{l}\text { Interaction of Above with } \\
\text { New York in Suspension }\end{array}$ & & & $\begin{array}{l}-2.56 \\
(5.03)\end{array}$ \\
\hline Ratio Loans to Assets & $\begin{array}{l}-2.94 \\
(3.89)\end{array}$ & $\begin{array}{l}-4.90 \\
(5.47)\end{array}$ & $\begin{array}{l}-2.78 \\
(3.56)\end{array}$ \\
\hline $\begin{array}{l}\text { Interaction of Above with } \\
\text { New York in Suspension }\end{array}$ & & & $\begin{array}{l}-2.43 \\
(5.16) \\
\end{array}$ \\
\hline Log Total Assets & $\begin{array}{l}-0.60 \\
(0.39)\end{array}$ & $\begin{array}{l}-0.18 \\
(0.52)\end{array}$ & $\begin{array}{l}-0.58 \\
(0.36) \\
\end{array}$ \\
\hline $\begin{array}{l}\text { Interaction of Above with } \\
\text { New York in Suspension }\end{array}$ & & & $\begin{array}{c}0.39 \\
(0.58) \\
\end{array}$ \\
\hline Constant & $\begin{array}{c}6.65 \\
(4.71) \\
\end{array}$ & $\begin{array}{c}5.85 \\
(5.81) \\
\end{array}$ & $\begin{array}{c}6.34 \\
(3.66) \\
\end{array}$ \\
\hline $\begin{array}{l}\mathrm{Chi}^{2} \text { Statistic that Reserve } \\
\text { and Distance Interactions } \\
\text { are Zero } \\
\left(\text { Prob }>\mathrm{Chi}^{2}\right)\end{array}$ & & & $\begin{array}{c}2.38 \\
(0.94)\end{array}$ \\
\hline Number of Observations & 167 & 152 & 319 \\
\hline Number of Suspensions & 15 & 9 & 24 \\
\hline
\end{tabular}

A negative number implies the variable increases the likelihood of suspension

Standard errors in parentheses

* - indicates significant at $10 \%$ level

** - indicates significant at 5\% level

*** - indicates significant at $1 \%$ level 